\title{
Binding of purified Bacillus sphaericus binary toxin and its deletion derivatives to Culex quinquefasciatus gut: elucidation of functional binding domains
}

\author{
COREEN OEI, ${ }^{*}$ JoHN HINDLEY and COLIN BERRY $\dagger$
}

Insecticidal Toxins Laboratory, Institute of Molecular and Cell Biology, National University of Singapore, 10 Kent Ridge Crescent, Singapore 0511

(Received 30 December 1991; accepted 13 April 1992)

\begin{abstract}
Highly larvicidal strains of Bacillus sphaericus produce a binary toxin composed of 51 and 42 kDa proteins which binds to sharply delineated regions of the gastric caecum and posterior midgut of susceptible larvae of the mosquito Culex quinquefasciatus. To investigate the role of the individual subunits and the organization of functional binding regions within the toxin, plasmids were constructed for the expression in Escherichia coli of the toxin proteins and their $\mathrm{NH}_{2}$ - and $\mathrm{COOH}$-terminal deletion derivatives as fusions with glutathione $S$-transferase (GST). Toxin proteins were purified by affinity chromatography followed by cleavage from the GST carrier with thrombin. The $\mathbf{L C}_{50}$ values for the purified toxin proteins and their deletion derivatives were determined. The binding patterns of fluorescently labelled toxin suggested that the $51 \mathrm{kDa}$ protein is the primary binding component of the toxin and mediates the regional binding and internalization of the $42 \mathrm{kDa}$ protein. Examination of the toxin deletion derivatives revealed that the $\mathrm{NH}_{2}$-terminal region of the $51 \mathrm{kDa}$ protein was required for binding to the larval gut, whilst the COOH-terminal region was responsible for interacting with the $42 \mathrm{kDa}$ protein. Toxicity was strongly correlated with the subsequent internalization of the toxin, probably by endocytosis.
\end{abstract}

\section{Introduction}

Bacillus sphaericus is an aerobic, Gram-positive, sporeforming bacterium which is ubiquitously distributed in soil and aquatic environments. A number of $B$. sphaericus strains are toxic to mosquito larvae, notably Culex, Anopheles and Mansonia species (Yousten, 1984; Cheong \& Yap, 1985). Larvicidal activity in highly toxic strains of $B$. sphaericus is principally associated with a parasporal crystal which contains several proteins, of which the 51 and $42 \mathrm{kDa}$ proteins (designated P51 and P42 respectively in this study) are the best characterized

* Author for correspondence. Tel. (65) 7723775; fax (65) 7791117.

$\dagger$ Present address: Department of Biochemistry, University of Wales College of Cardiff, PO Box 903, Cardiff CF1 1ST, UK.

\footnotetext{
Abbreviations: GST, glutathione $S$-transferase; P51, the $51 \mathrm{kDa}$ component of the $B$. sphaericus binary toxin; $\mathrm{P} 42$, the $42 \mathrm{kDa}$ component of the $B$. sphaericus binary toxin; $\mathrm{LC}_{50}$, the concentration of toxin resulting in $50 \%$ mortality of larvae; $A M G$, anterior midgut; CMG, central midgut; PMG, posterior midgut; GC, gastric caecum; FITC, fluorescein isothiocyanate; TRITC, tetramethylrhodamine isothiocyanate; IPTG, isopropyl $\beta$-D-thiogalactoside.
}

(Davidson, 1983; Baumann et al., 1985; Berry et al., 1991; Baumann et al., 1991). When assayed against mosquito larvae, both proteins were found to be necessary for toxicity, indicating that the $B$. sphaericus larvicide may act as a binary toxin (Broadwell et al., $1990 a, b$; Davidson et al., 1990; Baumann et al., 1991). Following ingestion of the toxin by larvae, the 51 and $42 \mathrm{kDa}$ proteins are processed to lower molecular mass forms of approximately 44 and $39 \mathrm{kDa}$ respectively (Broadwell \& Baumann, 1987; Davidson et al., 1987a, 1990; Aly et al., 1989; Broadwell et al., 1990a). Studies using binary toxin purified from the spores of $B$. sphaericus, a mixture of the 51 and $42 \mathrm{kDa}$ proteins, have shown that toxin binding occurs in the gastric caecum and posterior midgut of Culex larvae (Davidson, 1988). However, purification of the individual proteins from $B$. sphaericus has proved to be problematic (Broadwell et al., $1990 \mathrm{~b}$; Davidson et al., 1990), and hence the respective roles of the 51 and $42 \mathrm{kDa}$ proteins in toxin binding have remained unresolved.

In our previous work (Oei et al., 1990), we constructed a series of deletion mutants in which varying numbers of amino acid residues had been deleted from both the 
$\mathrm{NH}_{2}$ - and $\mathrm{COOH}$-termini of the 51 and $42 \mathrm{kDa}$ proteins of $B$. sphaericus strain 2297. The recombinant proteins expressed in Escherichia coli were assayed for toxicity against Culex quinquefasciatus larvae. The minimal regions of both proteins necessary for toxicity have been identified in our laboratory and others (Oei et al., 1990; Broadwell et al., 1990c; Clark \& Baumann, 1990; Sebo et al., 1990).

The availability of purified preparations of the different classes of truncated proteins from the various deletion mutants presents the opportunity to compare in vivo toxicity with the patterns of the binding of the toxin to target cells in the larval gut and also to analyse precisely the toxicities of the different deletion proteins. Here we describe studies using the purified 51 and $42 \mathrm{kDa}$ proteins and their deletion derivatives, labelled by direct coupling to isothiocyanate fluorochromes, to investigate the patterns of in vivo binding of the proteins in relation to their toxicity to $C$. quinquefasciatus larvae.

\section{Methods}

Materials. Restriction enzymes and DNA-modifying enzymes used in DNA manipulations were purchased from Boehringer Mannheim or New England Biolabs. Bovine thrombin, glutathione-agarose and the fluorochromes fluorescein isothiocyanate (FITC) and tetramethylrhodamine isothiocyanate (TRITC) were obtained from Sigma.

Media, bacterial strains and plasmids. E. coli strain $\mathrm{HB} 101 \mathrm{~F}^{-}$, hsdS20( $\left.r_{\overline{\mathrm{B}}}, m_{\overline{\mathrm{B}}}\right)$, recA13, supE44, ara-14, galK2, lacY1, proA2, $\left.r p s L 20\left(\mathrm{Str}^{\mathrm{r}}\right), x y l-5, m t l-1, \lambda^{-}\right]$was used for the propagation of plasmids and the expression of recombinant proteins. Plasmid pGEX-KG contains the glutathione $S$-transferase (GST) gene under the control of the tac promoter and has been described previously (Smith \& Johnson, 1988; Guan \& Dixon, 1991). Plasmids pRK42, pRK 37 and pCC2297$\mathrm{F}$, encoding the deletion derivatives of the $51 \mathrm{kDa}$ protein, and plasmids pME31 and pMN174, encoding the $42 \mathrm{kDa}$ protein and its deletion derivative, have been described elsewhere (Oei et al., 1990). Plasmid pRK24, containing a DNA fragment [nucleotides 509-1979 according to the published sequence of Baumann et al. (1988)], encoding the $51 \mathrm{kDa}$ protein (minus the first four codons), was generated as part of the pRK series (Oei et al., 1990). Plasmid pME23 contains a gene fragment (nucleotides 2023-3257) which encodes the $42 \mathrm{kDa}$ protein (minus the first four codons) and was generated as part of the pME series (Oei et al., 1990).

E. coli was cultured in Luria broth or $2 \times \mathrm{TY}$ liquid medium $(10 \mathrm{~g}$ yeast extract, $16 \mathrm{~g}$ tryptone and $5 \mathrm{~g} \mathrm{NaCl}$ in 1 litre) and supplemented with $60 \mu \mathrm{g}$ ampicillin $\mathrm{ml}^{-1}$ where necessary for plasmid maintenance. Isopropyl $\beta$-D-thiogalactoside (IPTG) at a final concentration of $0.2 \mathrm{~mm}$ was used to induce the expression of fusion proteins.

Mosquito larvae. The larvae of Culex quinquefasciatus were reared in our laboratory. Aedes aegypti larvae were obtained from the Insectarium of the Department of Microbiology, National University of Singapore

Construction of GST-toxin gene fusions. For our plasmid constructions, we utilized pGEX-KG, a vector which allows the IPTGinducible expression of a cloned gene as a fusion protein with GST (Smith \& Johnson, 1988; Guan \& Dixon, 1991). These GST-toxin fusion proteins were purified by affinity chromatography on glutathione agarose under non-denaturing conditions. The vector also encodes a thrombin recognition site (L-V-P-R-G-S) which allows the separation of the GST and toxin polypeptides by endopeptidolytic cleavage with thrombin (Chang, 1985). The vector pGEX-KG is a derivative of the vector pGEX-2T (Pharmacia), which has a glycine-rich linker incorporated adjacent to the thrombin site (Guan \& Dixon, 1991). This facilitated the cleavage of the fusion proteins while they were still attached to the glutathione-agarose and allowed a single-step purification of the recombinant toxin proteins.

(i) GST-P51 gene fusions. A $1.5 \mathrm{~kb} \mathrm{NcoI-XmnI} \mathrm{fragment} \mathrm{containing}$ the gene encoding the $51 \mathrm{kDa}$ protein (minus the first four codons) was excised from plasmid pRK24 and was made blunt-ended by treatment with Klenow polymerase. The DNA fragment was then ligated into the vector pGEX-KG which had previously been cut with $X b a I$ and the ends made blunt-ended by treatment with Klenow polymerase. This yielded the plasmid pKG51 (Fig. $1 a$ ), which had the $5^{\prime}$-end of the gene encoding the $51 \mathrm{kDa}$ protein inserted directly at the $3^{\prime}$ end of the GST gene, for the expression of an in-phase GST-P51 fusion protein.

The plasmids containing $\mathrm{NH}_{2}$ - and $\mathrm{COOH}$-terminal deletions of the P51 gene, which are denoted as the pKG51 $\Delta \mathrm{N}$ and pKG51 $\Delta \mathrm{C}$ series respectively, are shown schematically in Fig. 2. To construct gene fusions in which $\mathrm{NH}_{2}$-terminal deletions of P51 were coupled to GST, two different cloning procedures were utilized. Plasmid pK G51 $\triangle$ N34 was constructed by subcloning a $1.4 \mathrm{~kb} \mathrm{NcoI-XmnI} \mathrm{fragment} \mathrm{(which}$ had been treated with Klenow polymerase) from plasmid pRK 42 (Oei et al., 1990) into the NcoI-cut, Klenow-polymerase-treated vector pGEX-KG. A $1.4 \mathrm{~kb}$ DNA fragment was also isolated from plasmid pRK 37 (Oei et al., 1990) by digestion with $N c o I$ and $X m n I$ and filling in the ends with Klenow polymerase. This fragment was incubated overnight in ligation buffer with NcoI- cut pGEX-KG to allow the compatible NcoI ends to ligate. The DNA was then precipitated, subjected to phenol/chloroform extraction and treated with Klenow polymerase to blunt-end the unligated $N c o$ I end. The plasmid DNA was then recircularized and the plasmid containing the insert in the desired orientation (designated pKG51 $\Delta \mathrm{N} 45$ ) was selected. These steps were necessary to ensure that the $\mathrm{NH}_{2}$-terminal-deleted $51 \mathrm{kDa}$ protein was produced in-phase with the GST protein.

To create GST-COOH-terminal deletions of P51 gene fusions, the fragment encoding the $\mathrm{COOH}$-terminus of P51 was removed from pKG51 (Fig. 1 $a$ ) and was replaced with fragments encoding $3^{\prime}$ truncations of the gene as follows. Plasmid pKG51 was cut with HindIII, made blunt-ended with Klenow polymerase and restricted with either $A f I I I$ or $B g I I$. In both cases, the larger of the two fragments generated was isolated from low-melting-point agarose following electrophoresis. Plasmid pKG51 $\mathrm{C} 52$ was created by excising a $1.06 \mathrm{~kb}$ AfiII-SmaI fragment from plasmid pCC2297-F (Oei et al., 1990 ) and ligating it to the $A f I I / / H i n d I I I-c u t ~(b l u n t-e n d e d)$ pKG51. Similarly, to generate plasmid pKG51 $\triangle \mathrm{C} 56$, a $0 \cdot 2 \mathrm{~kb} B g / \mathrm{II}-A c c \mathrm{I}$ fragment was subcloned from pCC2297-F into pKG51 which had previously been restricted with HindIII, blunt-ended with Klenow polymerase and digested with $B g I I I$.

(ii) GST-P42 gene fusions. To construct plasmid pKG42 (Fig. 1b), which contains the gene encoding a GST-P42 fusion protein, the following DNA manipulations were performed. Plasmid pME23, which contains the gene encoding the $42 \mathrm{kDa}$ protein (minus the first four amino acids), was first digested with $S m a I$ and subsequently partially digested with $\mathrm{XbaI}$. A $1.23 \mathrm{~kb} X b a \mathrm{I}-S m a \mathrm{I}$ fragment was then isolated and ligated to the $X b a \mathrm{I}$-cut vector pGEX-KG. After $12 \mathrm{~h}$ incubation at $15^{\circ} \mathrm{C}$ to allow the compatible $X b a I$ ends to ligate, the DNA fragments were precipitated and subjected to phenol/chloroform extraction. The ends were then filled in with Klenow polymerase and the plasmid containing the insert was recircularized.

The plasmids containing the genes encoding $\mathrm{NH}_{2}{ }^{-}$and $\mathrm{COOH}-$ terminal deletions of the $42 \mathrm{kDa}$ protein (denoted as the pKG42 $\triangle \mathrm{N}$ 
(a)
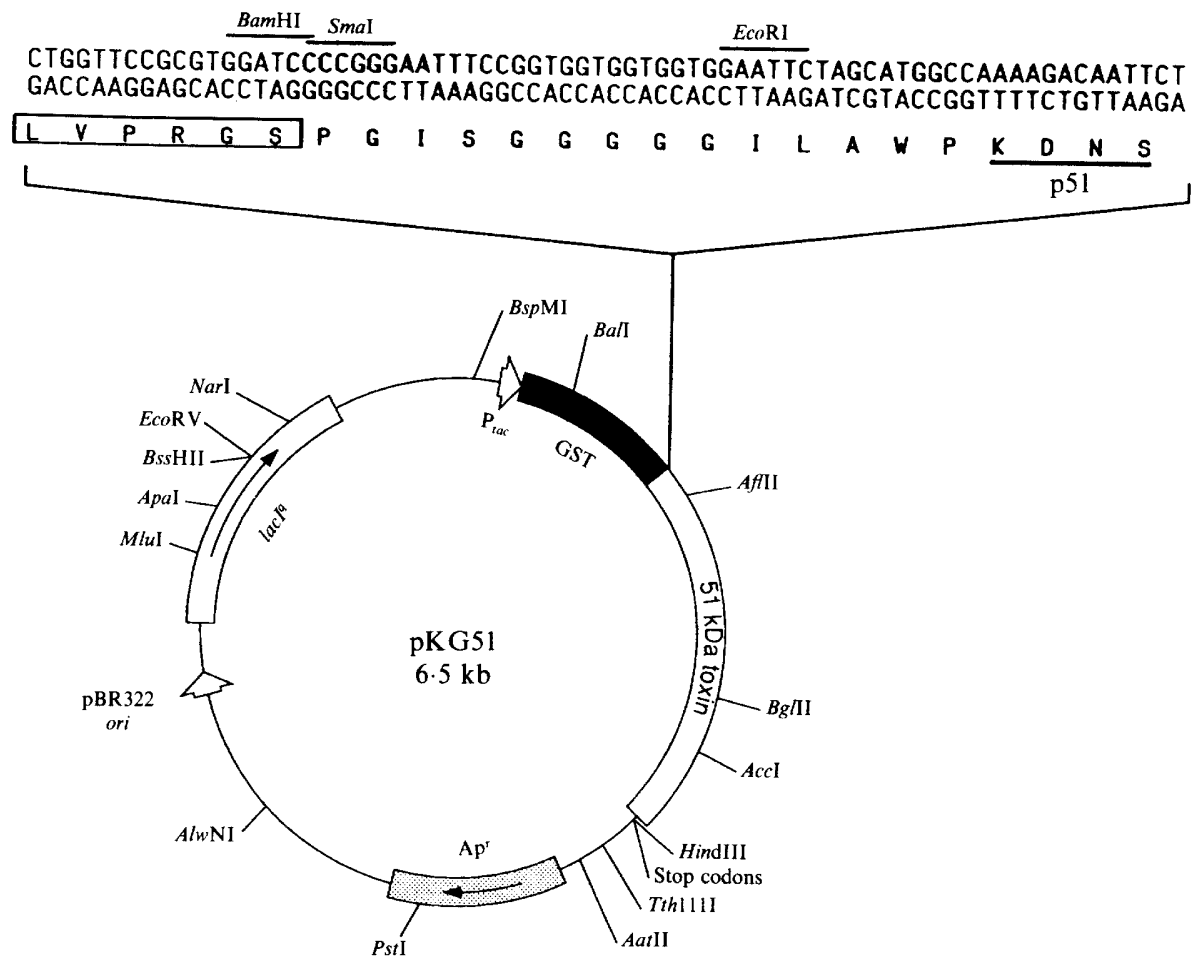

(b)
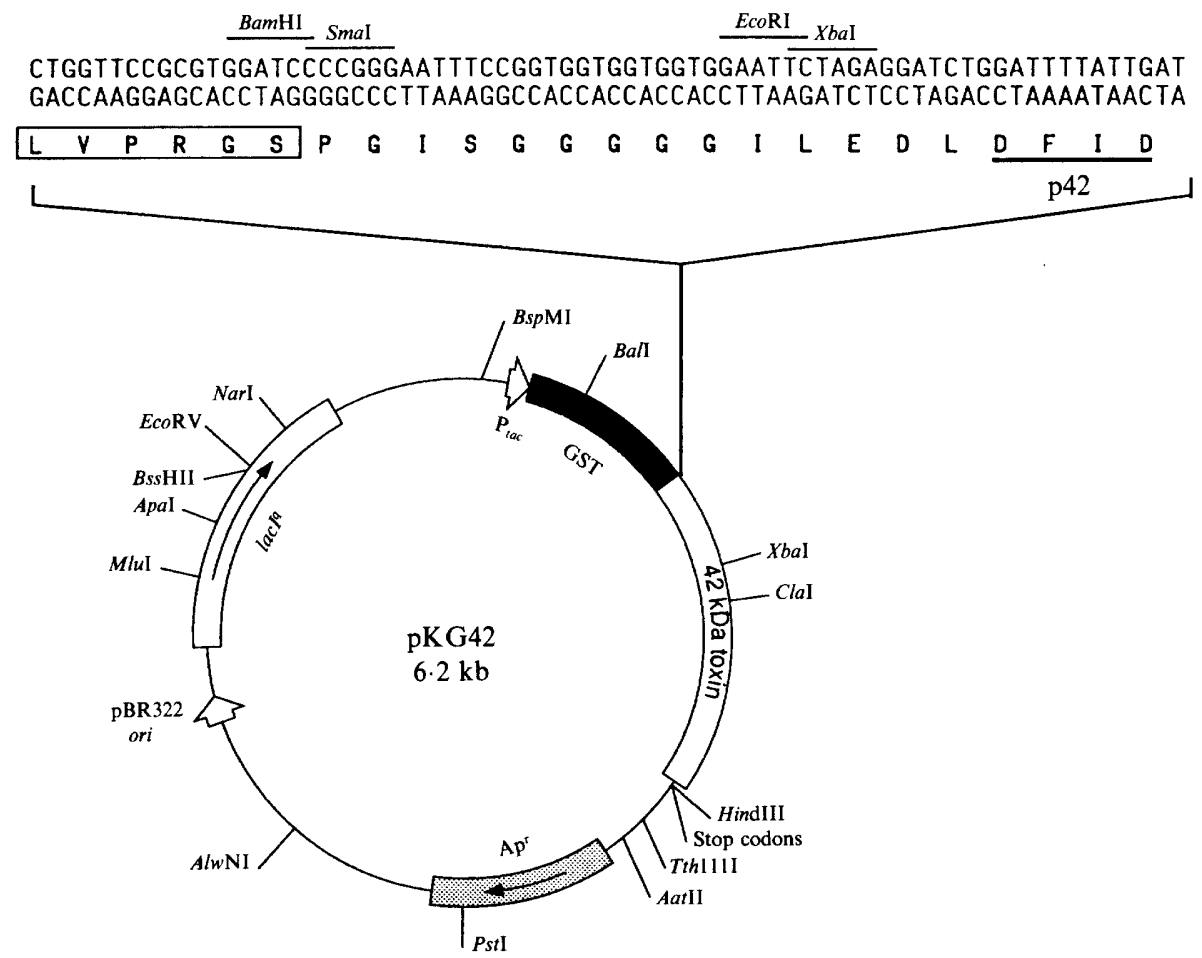

Fig. 1. Structure of plasmids $(a)$ pKG51 and $(b)$ pKG42 containing GST-toxin translational fusions. The GST gene segment is represented by the black box and the genes encoding the 51 and $42 \mathrm{kDa}$ proteins are represented by the open boxes. The nucleotide and amino acid sequences are shown for the linker connecting the GST and toxin gene fragments. The boxed amino acids designate the thrombin recognition sequence; the amino acids underlined indicate the start of the toxin protein sequences. The location of genes for ampicillin resistance $\left(\mathrm{Ap}^{\mathrm{r}}\right)$ and the lac repressor $\left(l a c I^{q}\right)$ are denoted by arrows in shaded and open boxes respectively. 


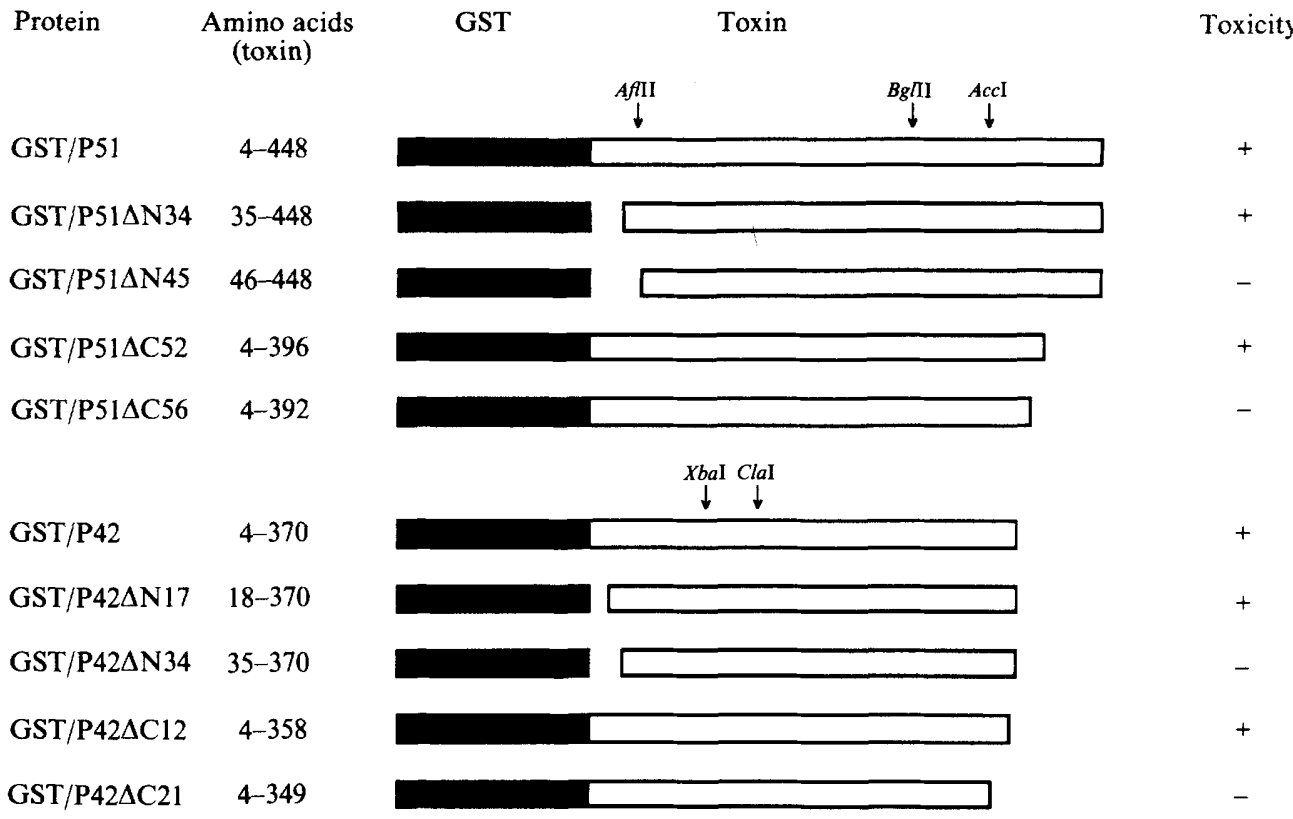

Fig. 2. Schematic representation of GST-toxin deletion mutants. The genes encoding the GST-toxin fusion proteins are shown with the black and open regions representing GST and B. sphaericus toxin segments, respectively. Below P51 and P42 (the full-length toxin proteins), the $\mathrm{NH}_{2}-$ and $\mathrm{COOH}$-terminal deletion constructs are shown schematically. The names of the toxin deletion derivatives indicate the number of amino acids deleted from either the $\mathrm{NH}_{2}$ - or the $\mathrm{COOH}$-terminus. The amino acids of the toxin sequences (e.g. 4-448) which are encoded are listed. The toxic activity of each recombinant protein (in combination with the other component of the binary toxin) is also indicated.

and pKG42 $\triangle \mathrm{C}$ series respectively) are shown schematically in Fig. 2. Plasmid pK G42 $\Delta \mathrm{N} 34$ was formed by ligating a $0.26 \mathrm{~kb}$ XbaI fragment from pMN174 (Oei et al., 1990) into the larger fragment isolated from the $X b a I$ digestion of pKG42. To construct pKG42 $\Delta$ N17, the plasmid pKG42 was digested with $X b a I$, the ends were filled in with Klenow polymerase and then a second digestion with $\mathrm{ClaI}$ was performed. The larger fragment was purified and ligated to a $0.48 \mathrm{~kb}$ RsaI-ClaI fragment from pME31 (Oei et al., 1990).

To construct GST-COOH-terminal deletions of P42 gene fusions, the fragment encoding the $\mathrm{COOH}$-terminus of $\mathrm{P} 42$ was removed from pKG42 (Fig. $1 b$ ) and was replaced with fragments encoding $3^{\prime}$ truncations of the gene as follows. pKG42 was digested with HindIII, the ends filled in with Klenow polymerase and then digested with ClaI. The larger $5.5 \mathrm{~kb}$ fragment was subsequently gel purified. Plasmid pK G42 $\Delta \mathrm{C} 12$ was created by ligating a $0.55 \mathrm{~kb}$ ClaI-EcoNI (bluntended) fragment from pME31 with the purified $5.5 \mathrm{~kb}$ fragment of pKG42. pCO3 was created by the ligation of a blunt-ended Sall$E c o R V$ gene fragment (nucleotides 2009-3066) encoding the $42 \mathrm{kDa}$ protein with a $\mathrm{COOH}$-terminal deletion of 21 amino acids into the SmaI site of pKK223-3. pK G42 $\triangle \mathrm{C} 21$ was subsequently constructed by ligating a $0.52 \mathrm{~kb}$ ClaI-BamHI (blunt-ended) fragment from $\mathrm{pCO} 3$ to the $5.5 \mathrm{~kb}$ DNA fragment from pKG42 described above.

Dideoxynucleotide sequencing of the pkG plasmids confirmed that the GST and toxin protein coding sequences were translationally in frame with each other and could therefore express the predicted GSTtoxin fusion proteins.

Expression, purification and thrombin cleavage of the fusion proteins. The recombinant plasmids were introduced into $E$. coli $\mathrm{HB} 101$ to express the GST-toxin fusion proteins. The expression of the fusion proteins was achieved as previously described (Guan \& Dixon, 1991) except that the cells were grown at $30^{\circ} \mathrm{C}$. After harvesting by centrifugation, cells were sonicated (W-380 Sonicator, Heats SystemsUltrasonics) for $2 \mathrm{~min}$ on ice at a $50 \%$ pulse and centrifuged for $10 \mathrm{~min}$ at $10000 \mathrm{~g}$ to remove the cell debris. Then $10 \mathrm{ml}$ of the supernatant was mixed with $10 \mathrm{ml} 50 \%(\mathrm{v} / \mathrm{v})$ glutathione-agarose beads for $1 \mathrm{~h}$ at $4{ }^{\circ} \mathrm{C}$ with gentle agitation. The beads were transferred to a $20 \mathrm{ml}$ polypropylene column (Bio-Rad) and washed with PBST [150 mM$\mathrm{NaCl}, 20 \mathrm{~mm}$-sodium phosphate $\mathrm{pH} 7.31 \%(\mathrm{v} / \mathrm{v})$ Triton X-100] until the $A_{280}$ of the eluate was less than 0.5 (approximately $250 \mathrm{ml}$ of wash buffer). The agarose beads were equilibrated by washing with $10 \mathrm{ml}$ thrombin cleavage buffer ( $50 \mathrm{~mm}-\mathrm{Tris} / \mathrm{HCl} \mathrm{pH} 8.0,150 \mathrm{~mm}-\mathrm{NaCl}$, $2.5 \mathrm{mM}-\mathrm{CaCl}_{2}, 0 \cdot 1 \% \beta$-mercaptoethanol) (Guan \& Dixon, 1991). The beads in the column were subsequently resuspended in $5 \mathrm{ml}$ of the thrombin cleavage buffer containing $2 \mu \mathrm{g}$ of bovine thrombin and incubated at room temperature with gentle shaking for $30 \mathrm{~min}$. After this time the column was allowed to drain and the proteins released by thrombin cleavage were collected in the buffer mixture that drained from the column.

SDS-PAGE and quantification of protein. SDS-PAGE was performed by the method of Laemmli (1970). Protein concentration was determined by the method of Bradford (1976), using bovine gamma globulin (Bio-Rad) as a standard.

Toxicity bioassays. Second-instar larvae of $C$. quinquefasciatus were used to determine the concentration of the toxin needed to cause $50 \%$ mortality $\left(\mathrm{LC}_{50}\right)$. Each concentration of the 51 and $42 \mathrm{kDa}$ proteins and their deletion derivatives was tested in duplicate. Ten larvae were introduced into $3 \mathrm{ml}$ water containing recombinant toxin proteins in a $3.5 \mathrm{~cm}$ Petri dish. Yeast was added to a final concentration of $1 \%(\mathrm{w} / \mathrm{v})$. Controls received yeast only. The surviving larvae were counted after 
$24 \mathrm{~h}$. Previous results showed that maximum toxicity occurred when the 51 and $42 \mathrm{kDa}$ proteins were present in approximately equal concentrations (Broadwell et al., 1990b; Davidson et al., 1990). Based on this observation, the bioassays were designed such that the $51 \mathrm{kDa}$ protein and its deletion derivatives were fed to the larvae in the presence of an equivalent concentration of $42 \mathrm{kDa}$ protein and vice versa.

Isothiocyanate labelling of proteins. The purified $51 \mathrm{kDa}$ protein and its deletion derivatives were labelled with FITC, while the purified $42 \mathrm{kDa}$ protein and its deletion derivatives were labelled with TRITC. The toxins were labelled by incubation in the dark at $4{ }^{\circ} \mathrm{C}$ for $8 \mathrm{~h}$ with either FITC or TRITC in $0.1 \mathrm{M}-\mathrm{Na}_{2} \mathrm{CO}_{3}$ ( $\mathrm{pH} \mathrm{9.0)}$ as described by Harlow \& Lane (1988). Unbound fluorochrome was separated from the conjugated protein by gel filtration using Sephadex G-50 (Pharmacia). The labelled proteins were stored at $-20^{\circ} \mathrm{C}$.

In vivo binding of the fluorescently labelled toxins. Third- or fourthinstar larvae were placed in solutions containing $10 \mu \mathrm{g} \mathrm{ml}^{-1}$ of FITCor TRITC-labelled proteins alone, or in combination with unlabelled proteins (Tables 2, 3, and 4). After 4-5 h of feeding, guts were dissected from the larvae and fixed on poly-L-lysine-coated glass slides (Davidson et al., 1987b; Davidson, 1988). Coverslips were then mounted onto the slides after the addition of Permafluor aqueous mounting medium (Lipshaw). The midgut specimens were observed using a Zeiss fluorescence microscope.

\section{Results}

\section{Purification and cleavage of the fusion proteins}

The constructs encoding P51, P42 and their deletion derivatives yielded approximately $0.5-1.5 \mathrm{mg}$ protein per litre of cells. $E$. coli cells containing plasmids pKG51 and pKG42 produced GST-toxin fusion proteins of 77 and $68 \mathrm{kDa}$ respectively $(26 \mathrm{kDa}$ of GST and 51 or $42 \mathrm{kDa}$ corresponding to each component of the binary toxin) (Fig. 3, lanes 2 and 4). Thrombin cleavage of the fusion proteins GST-P51 and GST-P42 resulted in two recombinant toxin proteins of approximately 51 and $42 \mathrm{kDa}$ (Fig. 3, lanes 3 and 5), leaving the GST protein bound to the agarose beads (Fig. 3, lane 6). Both recombinant proteins lack four $\mathrm{NH}_{2}$-terminal residues (M-C-D-S for the $51 \mathrm{kDa}$ protein and M-R-N-L for the $42 \mathrm{kDa}$ protein) compared to the primary translation products of the toxin genes (Baumann et al., 1988). Following thrombin cleavage, 13 amino acid residues (G-S-P-G-I-S-G-G-G-G-G-I-L) found in the 'glycine kinker' (Guan \& Dixon, 1991) and three additional amino acid residues remain attached to the $\mathrm{NH}_{2}-$ terminus of the toxin proteins (Fig. 1).

The GST-toxin deletion derivatives were also effectively purified by the same method, yielding fusion proteins of the molecular masses predicted from the nucleotide sequences (results not shown). After cleavage of the toxin deletion derivatives from the GST by thrombin, the deletion mutants were purified to homogeneity as shown by SDS-PAGE (Fig. 4). Unexpectedly,

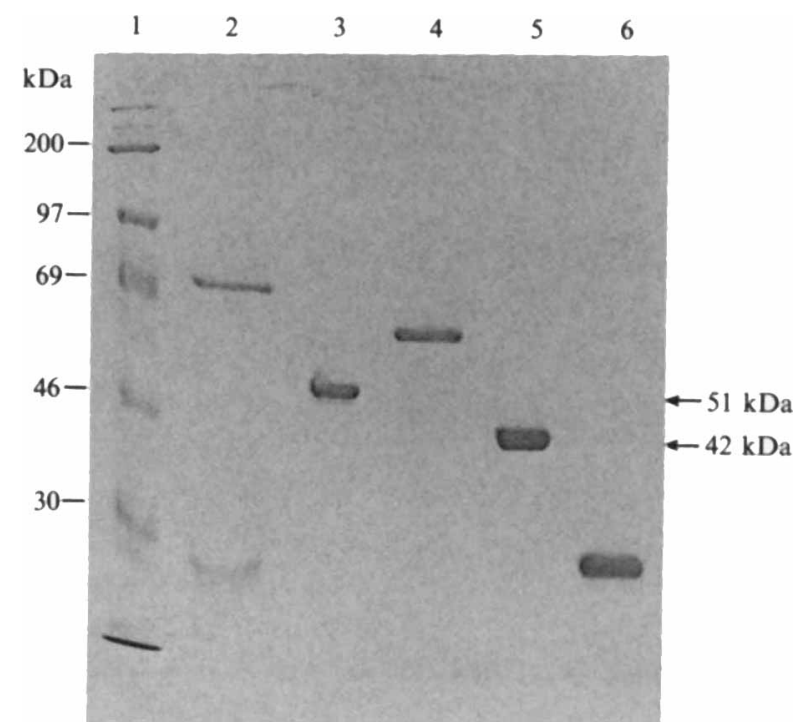

Fig. 3. Affinity-purified GST-P51 and GST-P42 fusion proteins and thrombin cleavage products. Purified GST-toxin fusion proteins were incubated with thrombin (for details, see Methods), and the samples were resolved by electrophoresis on a $0 \cdot 1 \% \mathrm{SDS} / 10 \%$ polyacrylamide gel, followed by staining with Coomassie blue. The sizes (kDa) and positions of the molecular mass markers are indicated in lane 1. Lanes 2 and 4 contain the fusion proteins GST-P51 and GST-P42 respectively, while lanes 3 and 5 contain the toxin proteins after cleavage from the GST carrier with thrombin. Lane 6 contains the GST moiety of the fusion proteins remaining on the glutathione affinity column after thrombin cleavage.

the deletion derivative P42 $\triangle \mathrm{N} 34$ migrated more slowly than P42 $\triangle$ N17 on SDS-PAGE (Fig. 4, lanes 8 and 9). As mentioned above, all the pKG plasmid constructs obtained in this study were sequenced across the junctions linking GST and the toxin proteins. The anomalous migration of the $\mathrm{P} 42 \Delta \mathrm{N} 34$ deletion derivative could have arisen from a change in conformation of the modified protein, as a result of a deletion of 34 amino acids from the $\mathrm{NH}_{2}$ terminus. The change in the threedimensional folding pattern of $P 42 \Delta N 34$ could result in reduced binding of SDS, and hence the retarded migration on SDS-PAGE. The anomalous migration of modified $B$. sphaericus toxin proteins has been observed previously (Clark \& Baumann, 1990).

\section{Toxicity bioassays against $C$. quinquefasciatus larvae}

Table 1 shows the $\mathrm{LC}_{50}$ values of purified P51, P42 and their deletion derivatives for the larvae of $C$. quinquefasciatus. Consistent with previous results (Broadwell et al., 1990a, b; Davidson et al., 1990; Oei et al., 1990), when P51 or P42 were fed alone to larvae they were not toxic, even at a concentration of $250 \mu \mathrm{g} \mathrm{ml}^{-1}$. A combination of the two proteins was toxic to larvae, confirming that the 


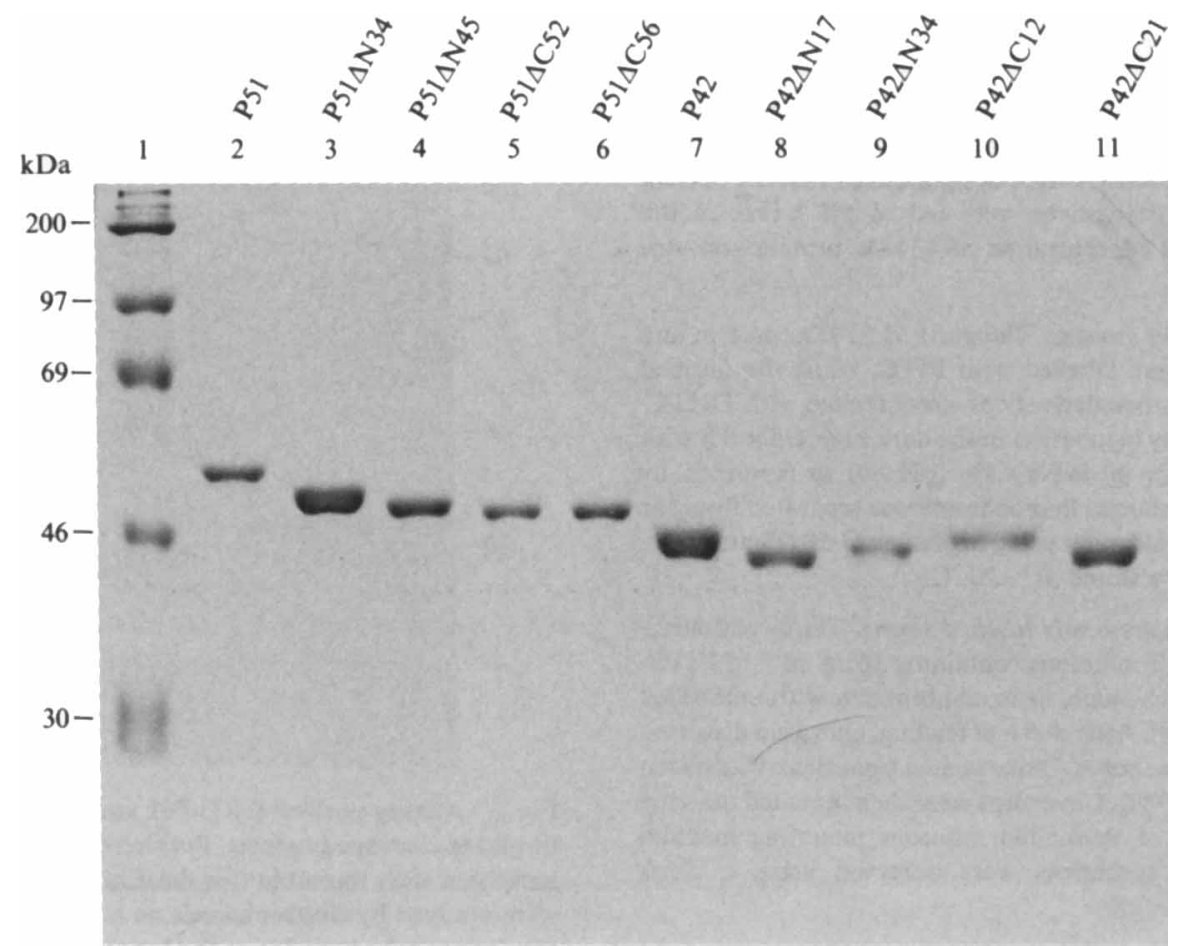

Fig. 4. SDS-PAGE of purified P51, $\mathrm{P} 42$ and their $\mathrm{NH}_{2}$ - and $\mathrm{COOH}$-terminal deletion derivatives expressed as GST fusion proteins. Purification and subsequent thrombin cleavage of the fusion proteins were as described in Methods. Purified recombinant proteins were analysed by electrophoresis through a $0.1 \%(\mathrm{w} / \mathrm{v}) \mathrm{SDS} / 12 \%(\mathrm{w} / \mathrm{v})$ polyacrylamide gel, followed by staining with Coomassie blue. Lanes 2-6 contain purified P51 and its deletion derivatives, while purified P42 and its deletion mutants are shown in lanes 7-11. The position and sizes $(\mathrm{kDa})$ of molecular weight markers are indicated in lane 1 .

Table 1. Larvicidal activities of purified recombinant 51 and $42 \mathrm{kDa}$ toxin proteins and their deletion derivatives towards C. quinquefasciatus larvae

\begin{tabular}{lr}
\hline Protein & $\mathrm{LC}_{50} *\left(\mathrm{ng} \mathrm{m}^{-1}\right)$ \\
\hline P51 & $30 \dagger$ \\
P51 $\Delta \mathrm{N} 34$ & $144 \dagger$ \\
P51 $\Delta \mathrm{N} 45$ & $>10000 \dagger$ \\
P51 $\Delta$ C52 & $784 \dagger$ \\
P51 $\Delta$ C56 & $>10000 \dagger$ \\
P42 & $30 \ddagger$ \\
P42 $\Delta$ N17 & $436 \ddagger$ \\
P42 $\Delta$ N34 & $>10000 \ddagger$ \\
P42 C12 & $142 \ddagger$ \\
P42 2 C21 & $>10000 \ddagger$ \\
\hline
\end{tabular}

* Concentration needed to kill $50 \%$ of C. quinquefasciatus larvae in a 24 h assay.

$\dagger$ Assayed in the presence of an equivalent amount of the $42 \mathrm{kDa}$ protein.

$\ddagger$ Assayed in the presence of an equivalent amount of the $51 \mathrm{kDa}$ protein.

larvicidal proteins may act as a binary toxin (Broadwell et al., 1990b; Davidson et al., 1990). Similarly, the deletion derivatives of P51 and P42 when fed alone to larvae were not toxic. The $\mathrm{LC}_{50}$ value of the combination of equal amounts of P51 and P42 was determined to be $30 \mathrm{ng} \mathrm{ml}^{-1}$ of each protein.

Compared to P51, the toxic $\mathrm{NH}_{2}$-terminal deletion derivative of the $51 \mathrm{kDa}$ protein $\mathrm{P} 51 \Delta \mathrm{N} 34$ exhibited a fivefold decrease in toxicity $\left(\mathrm{LC}_{50} 144 \mathrm{ng} \mathrm{ml} \mathrm{ml}^{-1}\right)$, whereas a $\mathrm{COOH}$-terminal deletion of 52 amino acids showed a greater decrease in toxicity $\left(\mathrm{LC}_{50} 784 \mathrm{ng} \mathrm{ml}^{-1}\right)$ when they were fed in combination with P42 (Table 1). In the case of the $42 \mathrm{kDa}$ protein, an $\mathrm{NH}_{2}$-terminal deletion of 17 amino acids (P51 $\Delta$ N17) led to a 15-fold reduction in toxicity $\left(\mathrm{LC}_{50} 436 \mathrm{ng} \mathrm{m}^{-1}\right)$ whilst the $\mathrm{COOH}$-terminal deletion derivative, $\mathrm{P} 42 \Delta \mathrm{C} 12$ showed only a fivefold reduction in toxicity $\left(\mathrm{LC}_{50} 142 \mathrm{ng} \mathrm{ml}^{-1}\right)$ when compared to the toxicity of P42. The other four truncated proteins were non-toxic at the highest concentration tested $\left(10 \mu \mathrm{g} \mathrm{ml}^{-1}\right)$.

Binding of FITC-labelled $51 \mathrm{kDa}$ protein and its deletion derivatives to the gut of $C$. quinquefasciatus larvae

The $51 \mathrm{kDa}$ protein and its deletion derivatives were assayed for their ability to bind to the midgut of $C$. quinquefasciatus larvae. When FITC-labelled P51 was fed to the larvae, intense fluorescence was observed at 

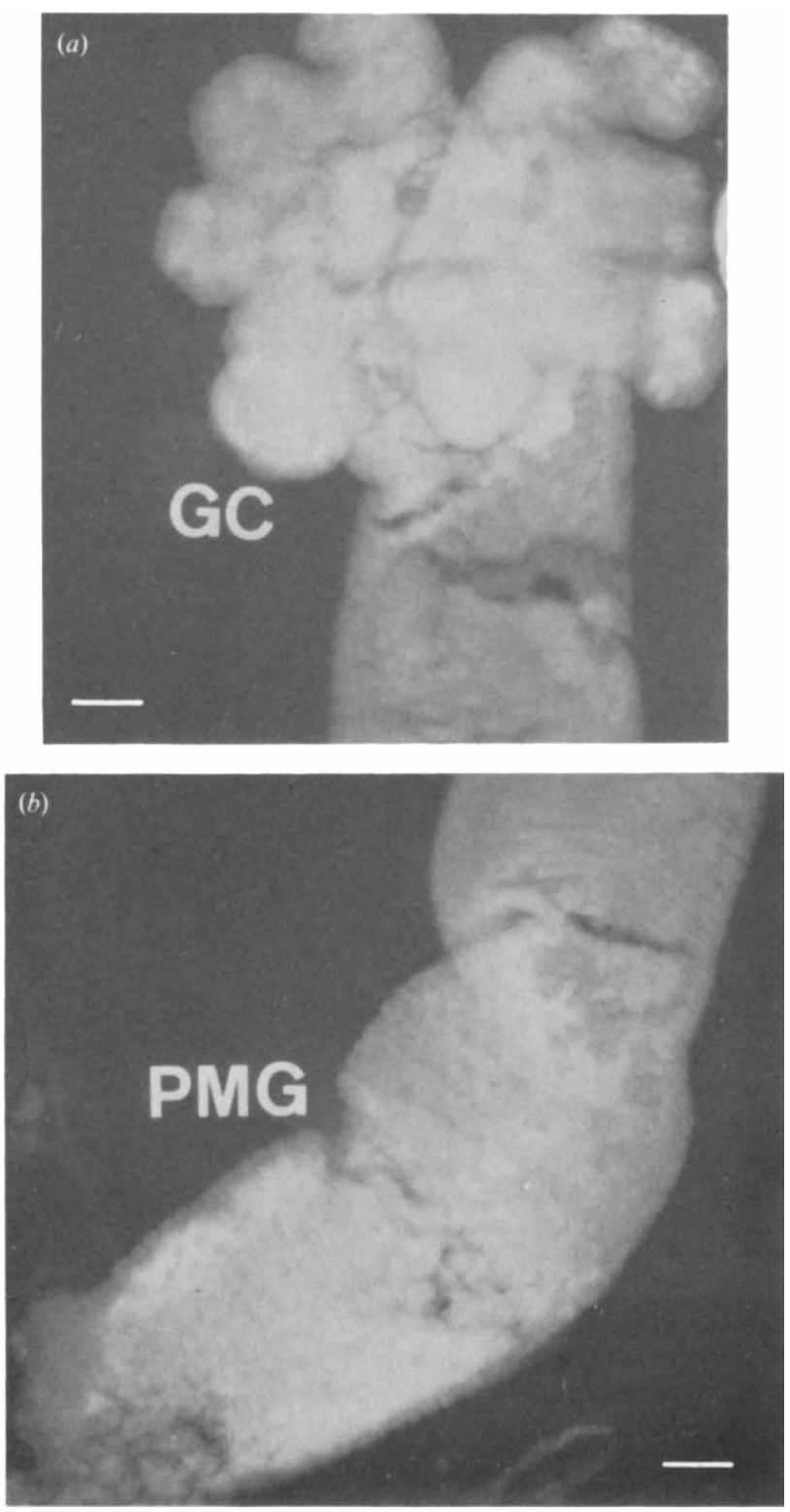

Fig. 5. Gut of $C$. quinquefasciatus larvae fed FITC-labelled P51 toxin. Fluorescence is very intense on the gastric caecum (GC; $a$ ) and on the posterior midgut (PMG; b). Bars, $20 \mu \mathrm{m}$.

Table 2. Binding patterns of FITC-labelled P51 and its deletion derivatives on the midgut of $C$. quinquefasciatus larvae

\begin{tabular}{lcc}
\hline \hline Protein & $\begin{array}{c}\text { Regional binding to } \\
\text { gastric caecum and } \\
\text { posterior midgut }\end{array}$ & $\begin{array}{c}\text { Binding to anterior } \\
\text { and central midgut }\end{array}$ \\
\hline P51 & + & - \\
P51 $\Delta$ N34 & + & - \\
P51 $\Delta$ N45 & - & - \\
P51 $\triangle$ C52 & + & - \\
P51 $\triangle$ C56 & + & - \\
\hline \hline
\end{tabular}

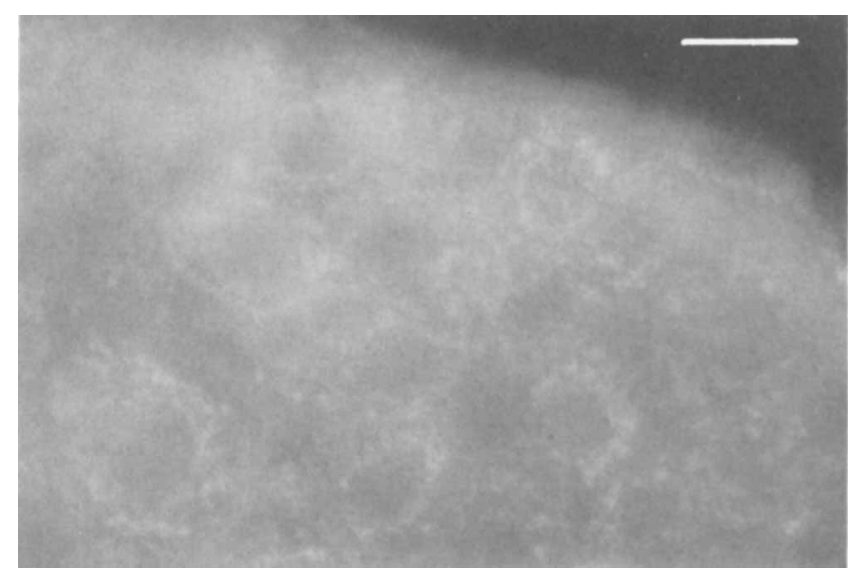

Fig. 6. Posterior midgut cells of $C$. quinquefasciatus larvae fed FITClabelled P51 and unlabelled P42. Internalization of the fluorescent labelled toxin as small, bright vesicles within the cells is apparent. Bar, $5 \mu \mathrm{m}$.

the gastric caecum (GC) and the posterior midgut (PMG) (Fig. 5). This pattern of binding is referred to as regional binding. The binding patterns of the deletion derivatives of $\mathrm{P} 51$ are summarized in Table 2. The $\mathrm{NH}_{2}-$ terminal deletion derivative which was still toxic, P51 $\triangle N 34$, exhibited a similar regional binding pattern to P51. However, the non-toxic $\mathrm{NH}_{2}$-terminal deletion protein, $\mathrm{P} 51 \Delta \mathrm{N} 45$, showed no binding to the larval gut (not shown). In contrast, the two $\mathrm{COOH}$-terminal deletions of the $51 \mathrm{kDa}$ protein, P51 $\triangle \mathrm{C} 52$ and P51 $\Delta \mathrm{C} 56$, exhibited the regional binding pattern found for P51. In order to differentiate between surface binding and internalization of the fluorescently-labelled toxin, the guts were examined at higher magnification. This revealed that binding of the FITC-labelled P51 or its deletion derivatives occurred at the cell surface with no evidence of internalization (results not shown). In the presence of unlabelled $\mathrm{P} 42$, although no change in the regional binding of FITC-labelled P51 occurred, observation at a higher magnification showed internalization of P51 into the cytosol of cells of the gut (Fig. 6).

\section{Binding patterns of TRITC-labelled $42 \mathrm{kDa}$ protein and its deletion derivatives}

When TRITC-labelled P42 was fed alone to larvae, fluorescence was observed over the entire larval gut, including the GC, the PMG and the anterior midgut (AMG) (Fig. 7). The same distribution of fluorescence was also observed with both the toxic and non-toxic TRITC-labelled $\mathrm{NH}_{2}-$ and $\mathrm{COOH}$-terminal deletion derivatives of P42 (results not shown). Internalization of the TRITC-labelled P42 or its deletion derivatives was 


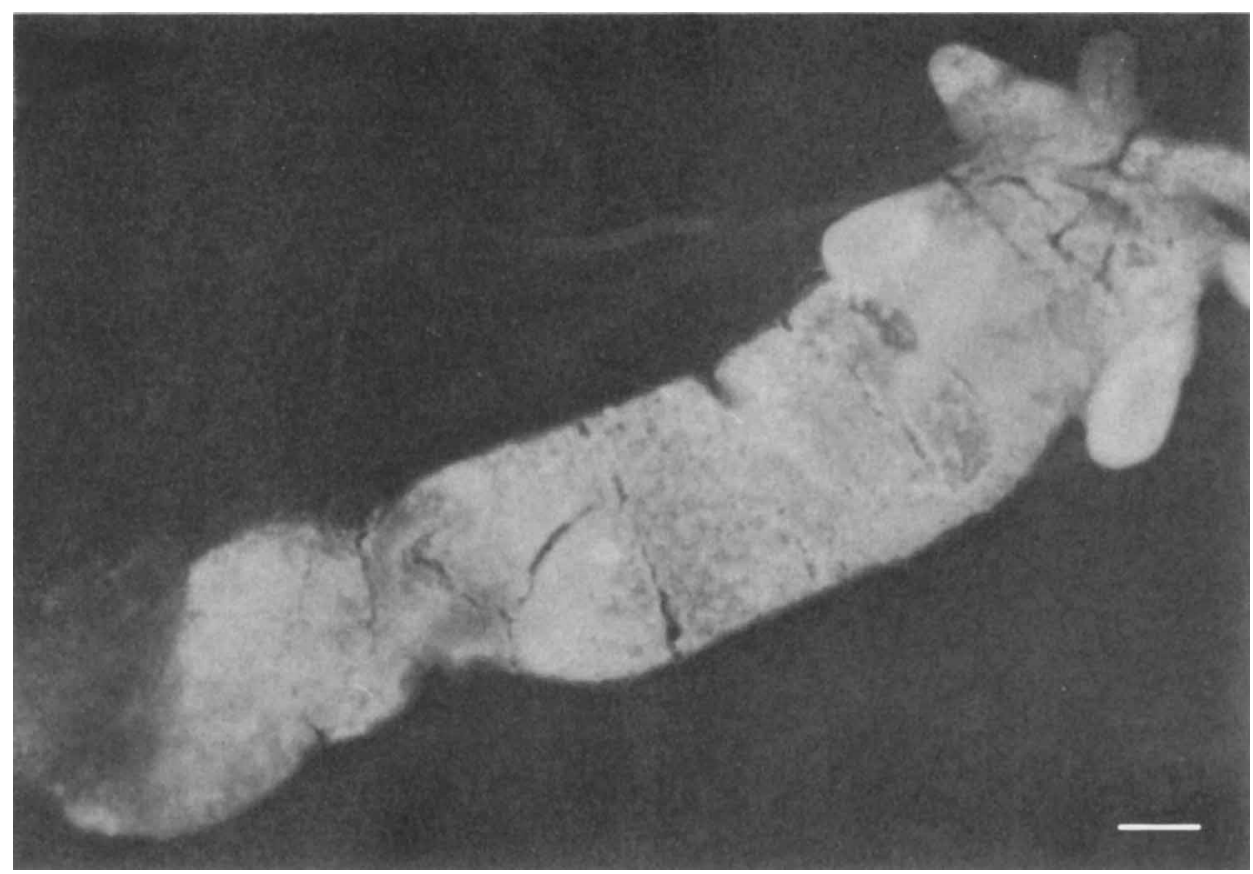

Fig. 7. Midgut of $C$. quinquefasciatus larvae fed TRITC-labelled P42. Strong fluorescence is present over the entire midgut and the gastric caecum. Bar, $20 \mu \mathrm{m}$.

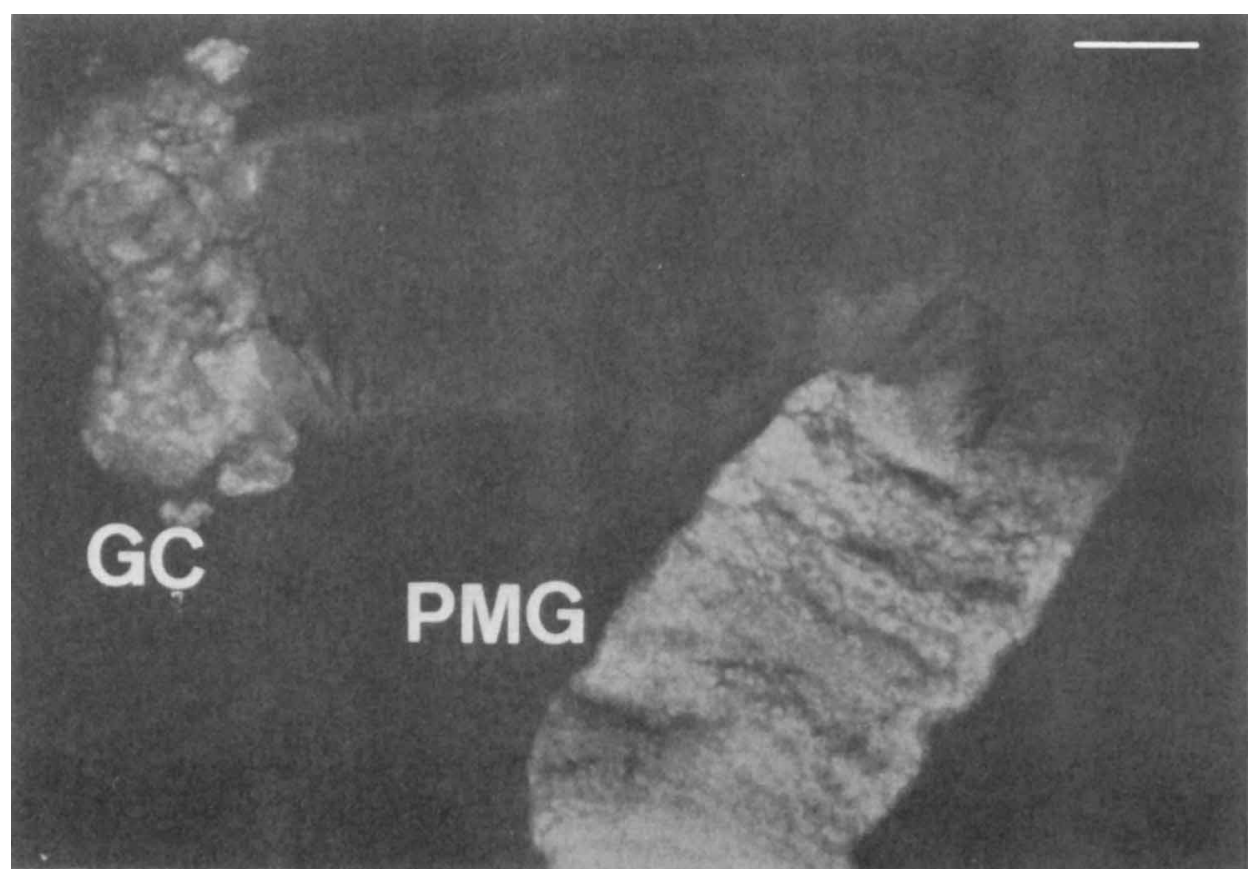

Fig. 8. Gut of $C$. quinquefasciatus larvae fed a combination of TRITC-labelled P42 and unlabelled P51. Note the strong regional binding of labelled P42 to the gastric caecum (GC) and posterior midgut (PMG) in the presence of P51. Bar, $50 \mu \mathrm{m}$.

not observed. When TRITC-labelled P42 was fed to larvae in the presence of unlabelled P51, binding of labelled P42 became strongly localized to the PMG and GC (Fig. 8). This regional binding was different from the non-specific binding observed when $\mathrm{P} 42$ alone was fed to larvae (compare Figs. 7 and 8 ) and seemed to be directed by $\mathrm{P} 51$, as the regional binding pattern was identical to that observed when larvae were fed FITC-labelled P51 


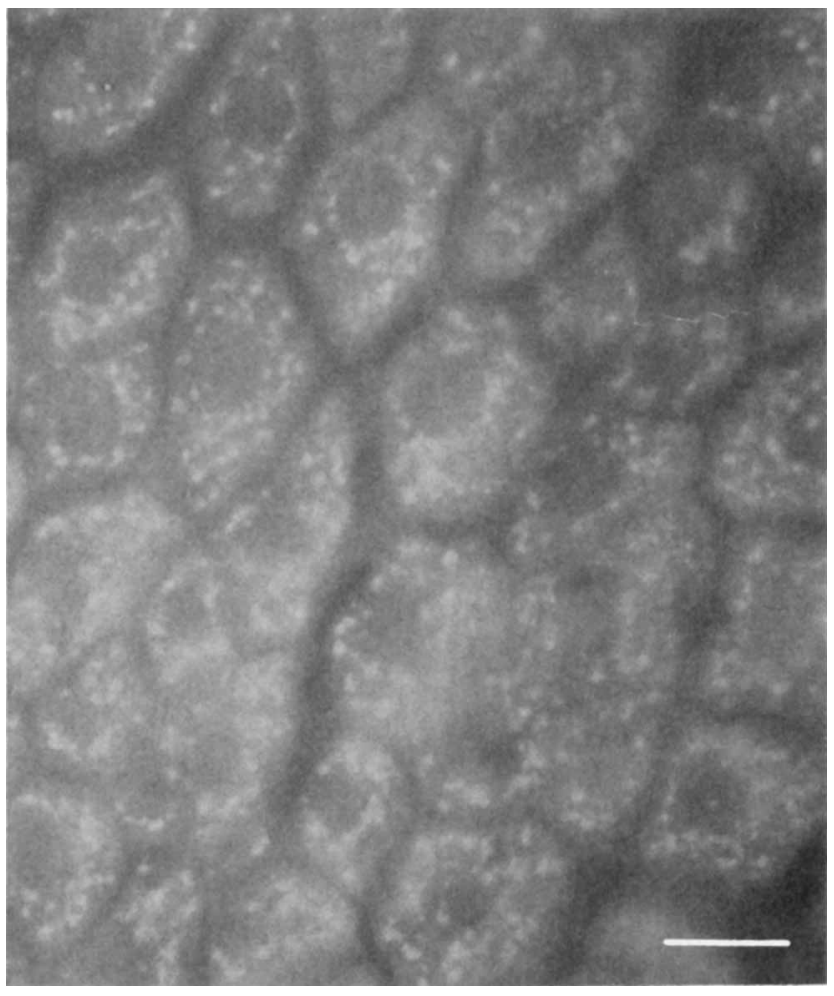

Fig. 9. Posterior midgut cells of $C$. quinquefasciatus larvae fed TRITClabelled P42 and unlabelled P51. Internalization of the fluorescent labelled toxin as small, bright vesicles within the cells is apparent. Bar, $5 \mu \mathrm{m}$.

alone (Fig. 5). The labelled P42 also appeared to become internalized as small, bright vesicles in the cytoplasm of the midgut cells (Fig. 9) (as reported previously with mixed labelled toxins: Davidson, 1988). No vesicles were observed in the nucleus (Fig. 9).

Table 3 summarizes the binding patterns of the TRITC-labelled $\mathrm{NH}_{2-}$ and $\mathrm{COOH}$-terminal deletion derivatives of $\mathbf{P} 42$ in the presence of unlabelled P51. A less toxic derivative of the $42 \mathrm{kDa}$ protein, $\mathrm{P} 42 \Delta \mathrm{N} 17$ (15fold reduction in toxicity), showed regional binding to the PMG and GC, although binding to the AMG and central midgut (CMG) region of the larvae was occasionally observed. There was no evidence of internalization of the labelled protein in the AMG or CMG. With the non-toxic derivatives P42 $\triangle$ N 34 and P42 $\triangle \mathrm{C} 21$, regional binding was completely abolished. The toxic $\mathrm{COOH}$-terminal deletion derivative $\mathrm{P} 42 \Delta \mathrm{C} 12$ had a similar binding pattern to that of full-length P42. Only P42 and the toxic deletion derivatives P42 $\Delta \mathrm{N} 17$ and $\mathrm{P} 42 \triangle \mathrm{C} 12$ were internalized by cells of the $\mathrm{GC}$ and PMG (Table 3).
Table 3. Binding patterns of TRITC-labelled P42 and its deletion derivatives in the presence of unlabelled P5I* on the midgut of $C$. quinquefasciatus larvae

\begin{tabular}{lccc}
\hline \hline $\begin{array}{l}\text { Protein } \\
\text { (labelled) }\end{array}$ & $\begin{array}{c}\text { Binding to gastric } \\
\text { caecum and } \\
\text { posterior midgut }\end{array}$ & $\begin{array}{c}\text { Binding to } \\
\text { anterior and } \\
\text { central midgut }\end{array}$ & $\begin{array}{c}\text { Internalization } \\
\text { of the labelled } \\
\text { protein }\end{array}$ \\
\hline P42 & + & - & + \\
P42 $\Delta$ N17 & + & ++ & + \\
P42 $\Delta$ N34 & + & + & - \\
P42 $\triangle$ C12 & + & - & + \\
P42 C 21 & + & + & - \\
\hline
\end{tabular}

* Larvae were fed with $10 \mu \mathrm{g}$ of TRITC-labelled test protein $\mathrm{ml}^{-1}$ and $10 \mu \mathrm{g}$ of unlabelled P51 ml-1.

† Occasional binding to this region.

Table 4. Binding patterns of TRITC-labelled P42 in the presence of unlabelled $P 51^{*}$ or its deletion derivatives on the midgut of $C$. quinquefasciatus larvae

\begin{tabular}{lccc}
\hline \hline $\begin{array}{l}\text { Protein } \\
\text { (unlabelled) }\end{array}$ & $\begin{array}{c}\text { Binding to gastric } \\
\text { caecum and } \\
\text { posterior midgut }\end{array}$ & $\begin{array}{c}\text { Binding to } \\
\text { anterior and } \\
\text { central midgut }\end{array}$ & $\begin{array}{c}\text { Internalization } \\
\text { of labelled P42 }\end{array}$ \\
\hline P51 & + & - & + \\
P51 $\Delta$ N34 & + & - & + \\
P51 $\Delta$ N45 & + & + & - \\
P51 $\Delta$ C52 & + & $+\dagger$ & + \\
P51 C56 & + & + & - \\
\hline \hline
\end{tabular}

* Larvae were fed with $10 \mu \mathrm{g}$ of TRITC-labelled P42 $\mathrm{ml}^{-1}$ and $10 \mu \mathrm{g}$ of unlabelled P51 or its deletion derivatives $\mathrm{ml}^{-1}$.

† Occasional binding to this region.

Effect of truncations of unlabelled $51 \mathrm{kDa}$ protein on the binding of TRITC-labelled $42 \mathrm{kDa}$ protein

As described above, the specific regional binding of TRITC-labelled P42 only occurred in the presence of P51. It was therefore of interest to study the interaction of the 51 and $42 \mathrm{kDa}$ proteins in the larval gut, as well as the effect of $\mathrm{NH}_{2}$ - or $\mathrm{COOH}$-terminal deletions of $\mathrm{P} 51$ on the binding patterns of the TRITC-labelled P42. The results of these experiments are summarized in Table 4. Labelled P42, in the presence of a toxic derivative of the $51 \mathrm{kDa}$ protein $\mathrm{P} 51 \Delta \mathrm{N} 34$, showed distinct regional binding to the GC and PMG. However, in the presence of the non-toxic derivatives P51 $\Delta \mathrm{N} 45$ and P51 $\Delta \mathrm{C} 56$, labelled $P 42$ bound non-specifically over the entire larval gut. When labelled P42 was fed in combination with an unlabelled P51 derivative, P51 $\Delta$ C52, which shows 
reduced toxicity (Table 1 ), there was strong fluorescence in the GC and PMG, but binding to the AMG and CMG regions was occasionally observed as well (Table 4). In the presence of the toxic dervatives P $51 \triangle \mathrm{N} 34$ and $\mathrm{P} 51 \triangle \mathrm{C} 52$, internalization of the labelled $\mathrm{P} 42$ was observed in the GC and PMG regions.

\section{Binding of fluorescently labelled 51 and $42 k D a$ proteins to the gut of Aedes aegypti larvae}

It has previously been shown that $A$. aegypti larvae do not bind the FITC-labelled mixed toxin proteins isolated from the spores of $B$. sphaericus (Davidson, 1988). Similarly in this study, no binding was observed when $A$. aegypti was fed with only FITC-labelled P51 (results not shown). When TRITC-labelled P42 was fed alone or in combination with unlabelled P51, binding of the labelled P42 over the entire midgut was observed (results not shown). The labelled $42 \mathrm{kDa}$ protein appeared to bind to the lumen edge of the midgut cells, but was not internalized in vesicles.

\section{Discussion}

To investigate the individual roles of the $B$. sphaericus 51 and $42 \mathrm{kDa}$ toxin proteins in mediating toxicity in the mosquito larval gut, it was necessary to obtain purified protein preparations. In this study, we used the GST fusion protein purification system for the expression and rapid purification of milligram quantities of the 51 and $42 \mathrm{kDa}$ proteins as well as their $\mathrm{NH}_{2-}^{-}$and $\mathrm{COOH}$ terminal deletion derivatives. The 51 and $42 \mathrm{kDa}$ proteins produced in this study retained toxin activity and were easily purified with yields of up to $1.5 \mathrm{mg}$ protein per litre of culture.

The effects of the various deletions of the 51 and $42 \mathrm{kDa}$ proteins on the $\mathrm{LC}_{50}$ of the toxins assayed against $C$. quinquefasciatus larvae (Table 1) paralleled results of previous studies in which deletion mutants were produced (Oei et al., 1990; Broadwell et al., 1990c; Clark \& Baumann, 1990). However, in these earlier studies, $\mathbf{L C}_{50}$ values were given in terms of concentrations of bacterial cells expressing, or amorphous inclusions containing, the proteins (Broadwell et al., 1990c; Clark \& Baumann, 1990). A limitation of using bacterial cells for the determination of $\mathrm{LC}_{50}$ is that changes in the level of expression of the recombinant proteins are indistinguishable from changes in the intrinsic potency of the toxins produced. By assaying the toxicity of the purified proteins instead of bacterial cells expressing the proteins, we can be confident that our results (Table 1) reflect the true toxicity of our recombinant toxin proteins.
In this study we have investigated the in vivo binding of the $B$. sphaericus toxin proteins to the gut of $C$. quinquefasciatus larvae in order to examine the initial binding events leading to intoxication and cell death. It has been previously demonstrated that FITC-labelled toxin isolated from the spores of $B$. sphaericus bound to discrete regions of the PMG and GC of the susceptible larvae of C. quinquefasciatus (Davidson, 1988, 1989). Internalization of the toxin as small, bright vesicles was also observed. At the time it was believed that the regional binding pattern of the FITC-labelled toxin was solely due to the action of the $42 \mathrm{kDa}$ protein (Davidson, 1988). However recent studies have shown that the $42 \mathrm{kDa}$ protein preparations used were contaminated with lower-molecular-mass derivatives of the the $51 \mathrm{kDa}$ protein (Broadwell et al., 1990 b; Davidson et al., 1990, Baumann et al., 1991) so that the reported binding patterns of the FITC-labelled proteins were due to a mixture of the 51 and $42 \mathrm{kDa}$ proteins. In this work, we have separately cloned, expressed and purified the 51 and $42 \mathrm{kDa}$ proteins as well as their $\mathrm{NH}_{2}-$ and $\mathrm{COOH}-$ terminal deletion derivatives. Using the GST fusion protein system, there was no possibility of crosscontamination between the two proteins (or their deletion derivatives) during their preparation and purification.

In this study, using individually purified toxin proteins, FITC-labelled P51 bound regionally to the PMG and $\mathrm{GC}$ when it was fed alone to $C$. quinquefasciatus larvae, and no internalization of the labelled protein was observed. In the presence of P51, the binding pattern of TRITC-labelled P42 changed from a non-specific binding to a regional P51-directed binding. Internalization of P42 was observed in the presence of P51 but did not occur with P42 alone. P51 was also internalized only in the presence of $P 42$. The results indicate that the presence of P51 was necessary for the regional binding and internalization of P42. We suggest that the $51 \mathrm{kDa}$ protein may function as the binding component of the binary toxin, and directs the binding of the $42 \mathrm{kDa}$ protein to the sites in the larval gut where toxicity occurs, i.e. the GC and PMG.

Davidson et al. (1990) have shown that the $51 \mathrm{kDa}$ protein can remain associated with the midgut tissue for up to $24 \mathrm{~h}$ after feeding $E$. coli cells containing the protein to larvae and that this protein remains available to interact with the $42 \mathrm{kDa}$ protein to cause mortality. In contrast, larvae fed cells containing the $42 \mathrm{kDa}$ protein were not killed when they were given cells containing the $51 \mathrm{kDa}$ protein $24 \mathrm{~h}$ later. Therefore from the results of our work (Davidson et al., 1990; this study), we suggest that the regional binding of P51 to the GC and PMG is a specific and tight binding whereas the binding of P42 in the absence of P51 is relatively weak and non-specific. 
We propose that the tight binding of $\mathrm{P} 51$ serves to direct the subsequent binding of P42 due to a strong interaction between the two proteins. Previous work (Narasu \& Gopinathan, 1986; Sgarella \& Szulmajster, 1987) has shown that the 51 and $42 \mathrm{kDa}$ proteins associate very strongly with one another, and they were copurified by several standard protein purification techniques (Davidson et al., 1990). It has been suggested that tight binding by the binding component of a binary toxin serves to increase the local concentration of the active component at the membrane surface, and so increase the possibility of penetration of the active component (van Heyningen, 1982). In the case of $B$. sphaericus binary toxin, the function of P51 in localizing P42 to the GC and PMG, which are the sites of cytopathogenicity, is consistent with the proposed role of the $51 \mathrm{kDa}$ protein as the binding component.

Davidson (1989) examined the binding patterns of FITC-labelled toxin isolated from $B$. sphaericus spores to the midgut cells of the non-susceptible larvae of $A$. aegypti and found that the lack of toxicity of the larvicide to this species was due to the absence of binding of the toxin. In this study, we found no binding of P51 to the midgut of $A$. aegypti, and a non-regional distribution of P42 binding in the presence or absence of P51 (a distribution comparable to that seen in the absence of P51 in guts of $C$. quinquefasciatus). However, $A$. aegypti larvae could still be killed when the $B$. sphaericus toxin was present at a very high dose (100-1000-fold greater than required for $C$. quinquefasciatus) (Lacy \& Undeen, 1986). The increase in the amount of the toxin could result in sufficient toxin being present at the susceptible sites of the gut to cause mortality. We propose that binding of P51 to a larval gut receptor is likely to be the crucial first step leading to toxicity and that the hostrange specificity of the toxin is attributable to the receptor affinity of P51.

The precise role of the $42 \mathrm{kDa}$ protein is unresolved but analogies with other binary toxins would suggest that this protein might be the active component following internalization (Simpson et al., 1987; Singh et al., 1989). Schroeder et al. (1989) have demonstrated that in a toxinresistant cell line of $C$. quinquefasciatus, binding and internalization of the toxin may occur without resulting in cell death. They concluded that the primary lethal action of the toxin occurred after initial interactions with the cell membrane and internalization. This conclusion is consistent with the proposed role of the $42 \mathrm{kDa}$ protein as the active component of the $B$. sphaericus binary toxin.

The finding that the $51 \mathrm{kDa}$ protein was the binding component of the binary toxin of $B$. sphaericus led us to investigate the relationship of binding to toxicity for truncated P51 derivatives. The toxic mutant protein P51 1 N34 exhibited regional binding to the GC and
PMG but there was a total loss of binding for the nontoxic deletion mutant P51 $\Delta \mathrm{N} 45$. We suggest therefore that the $\mathrm{NH}_{2}$-terminal region located between amino acid residues 34 and 45 may be part of the receptorbinding domain of the $51 \mathrm{kDa}$ protein. Deletions of the $\mathrm{COOH}$-terminus of P51 (the toxic P51 $\triangle \mathrm{C} 52$ and the nontoxic P51 $\Delta$ C56) had no effect on the regional binding of the $51 \mathrm{kDa}$ protein, indicating that the $\mathrm{COOH}$-terminus of P51 is not involved in the binding step. However, these deletions resulted in a loss of the ability (P51 $\Delta \mathrm{C} 56)$ or a decrease in the ability (P51 $\Delta \mathrm{C} 52)$ of these proteins to direct the regional binding of $\mathrm{P} 42$. In addition, internalization of P42 was observed when this protein was fed together with the toxic $\mathrm{COOH}$-terminal deletion protein (P51 $\triangle \mathrm{C} 52)$ but not with the non-toxic P51 deletion mutant (P51 $\Delta \mathrm{C} 56)$, suggesting that toxin internalization is important for activity. These results strongly suggest that the COOH-terminal region of P51 is likely to be involved in binding and interacting with $\mathrm{P} 42$ prior to the internalization event. Evidence that P51 and P42 associate very strongly has been presented elsewhere (Davidson et al., 1990), and we propose that the binding of P42 to P51 or to a P51-receptor complex is mediated via the $\mathrm{COOH}$-terminal region of the $\mathrm{P} 51$ protein. The 26-fold decrease in toxicity of P51 $\Delta$ C 52 compared to P51 could be explained by a decrease in affinity of the mutant protein towards $\mathrm{P} 42$ as a result of the deletion, while loss of a further four amino acids totally abolished the binding of P51 $\triangle \mathrm{C} 56$ to $\mathrm{P} 42$. The observation that labelled P51 was only internalized in the presence of unlabelled P42 suggests that internalization of the P51P42 complex or the P51-P42-receptor complex occurred, possibly by receptor-mediated endocytosis as previously described (Davidson et al., 1987b; Davidson, 1988).

Loss of toxicity in both $\mathrm{NH}_{2}$ - and $\mathrm{COOH}$-terminally deleted P42 derivatives paralleled their loss of binding to P51 or to the P51-receptor complex. This suggests that both the $\mathrm{NH}_{2}$ - and $\mathrm{COOH}$-termini of $\mathrm{P} 42$ are involved in this interaction. However, in a deletion derivative of the $42 \mathrm{kDa}$ protein showing a 15 -fold decrease in toxicity (P42 $\Delta$ N17), occasional binding to the AMG and CMG in addition to regional binding to the PMG and GC was observed, possibly due to a decrease in binding affinity for the $51 \mathrm{kDa}$ protein.

In conclusion, we propose here a scheme for the initial events of binding and interaction of the binary toxin of B. sphaericus. Our studies show that P51 (or its gutactivated form) binds specifically to the GC and PMG of the larval gut of $C$.quinquefasciatus, and that this binding is mediated via the $\mathrm{NH}_{2}$-terminal region of the protein. The bound P51 contains a site at its $\mathrm{COOH}$-terminus with which P42 (or its gut-activated form) interacts, and subsequently the P51-P42 complex or possibly a P51- 
P42-receptor complex is internalized via endocytosis. In this study we have elucidated the initial sequence of interactions of the 51 and $42 \mathrm{kDa}$ proteins with the target cells in the insect gut and have suggested a possible role for the $51 \mathrm{kDa}$ protein in toxicity. Our work has also revealed a strong correlation between toxicity and internalization of the toxin. Further studies on the $B$. sphaericus toxin should concentrate on the mechanism of action by which the toxin causes cell death after binding and internalization.

We would like to thank Dr Yue Wang for the kind gift of the vector pGEX-KG, Dr Y. H. Tan and Dr Wanjin Hong for critically reading the manuscript, and Judith Funkhouser and Valerie Seah for their advice on fluorescence microscopy.

\section{References}

Aly, C., Mulla, M. S. \& Federici, B. A. (1989). Ingestion, dissolution and proteolysis of the Bacillus sphaericus toxin by mosquito larvae. Journal of Invertebrate Pathology 53, 12-20.

Baumann, P., Unterman, B. M., Baumann, L., Broadwell, A. H., AbBene, S. J. \& Bowditch, R. D. (1985). Purification of the larvicidal toxin of Bacillus sphaericus and evidence for high molecular-weight precursors. Journal of Bacteriology 163, 738-747.

BaumanN, L., Broadwell, A. H. \& BaumanN, P. (1988). Sequence analysis of the mosquitocidal toxin genes encoding the 51.4- and 41.9-kilodalton proteins from Bacillus sphaericus 2362 and 2297. Journal of Bacteriology 170, 2045-2050.

Baumann, P., Clark, M. A., Baumann, L. \& Broadwell, A. H. (1991). Bacillus sphaericus as a mosquito pathogen: properties of the organism and its toxins. Microbiological Reviews 55, 425-436.

BerRy, C., Hindley, J. \& OEI, C. (1991). The Bacillus sphaericus toxins and their potential for biotechnological development. In Biotechnology for Biological Control of Pests and Vectors, pp. 35-51. Edited by K. Maramorosch. Florida: CRC Press.

BRADFORD, M. M. (1976). A rapid and sensitive method for the quantitation of microgram quantities of protein utilizing the principle of protein-dye binding. Analytical Biochemistry 72, 248254.

Broadwell, A. H. \& Baumann, P. (1987). Proteolysis in the gut of mosquito larvae results in further activation of the Bacillus sphaericus toxin. Applied and Environmental Microbiology 53, 1333-1337.

Broadwell, A. H., BaumanN, L. \& BaumanN, P. (1990a). The 42- and 51-kilodalton mosquitocidal proteins of Bacillus sphaericus 2362: construction of recombinants with enhanced expression and in vivo studies of processing and toxicity. Journal of Bacteriology 172, 22172223.

Broadwell, A. H., BaumanN, L. \& Baumann, P. (1990b). Larvicidal properties of the 42 and 51 kilodalton Bacillus sphaericus proteins expressed in different bacterial hosts: evidence for a binary toxin. Current Microbiology 21, 361-366.

Broadwell, A. H., Clark, M. A., Baumann, L. \& Baumann, P. $(1990 \mathrm{c})$. Construction by site-directed mutagenesis of a 39-kilodalton mosquitocidal protein similar to the larva-processed toxin of Bacillus sphaericus 2362. Journal of Bacteriology 172, 4032-4036.

CHANG, J.-Y. (1985). Thrombin specificity. Requirement for apolar amino acids adjacent to the thrombin cleavage site of polypeptide substrate. European Journal of Biochemistry 151, 217-224.

CheONG, W. C. \& YAP, H. H. (1985). Bioassays of Bacillus sphaericus (strain 1593) against mosquitoes of public health importance in Malaysia. Southeast Asian Journal of Tropical Medicine and Public Health 16, 54-58.
Clark, M. A. \& Baumann, P. (1990). Deletion analysis of the 51kilodalton protein of the Bacillus sphaericus 2362 binary mosquitocidal toxin: construction of derivatives equivalent to the larvaprocessed toxin. Journal of Bacteriology 172, 6759-6763.

DAVIDSON, E. W. (1983). Alkaline extraction of toxin from spores of the mosquito pathogen, Bacillus sphaericus strain 1593. Canadian Journal of Microbiology 29, 271-275.

DAvidson, E. W. (1988). Binding of the Bacillus sphaericus (Eubacteriales: Bacillaceae) toxin to midgut cells of mosquito (Diptera: Culicidae) larvae: relationship to host range. Journal of Medical Entomology 25, 151-157.

DAvidson, E. W. (1989). Variation in binding of Bacillus sphaericus toxin and wheat germ agglutinin to larval midgut cells of six species of mosquito. Journal of Invertebrate Pathology 53, 251-259.

Davidson, E. W., Bieber, A. L., Meyer, M. \& Shellabarger, C. (1987a). Enzymatic activation of the Bacillus sphaericus mosquito larvicidal toxin. Journal of Invertebrate Pathology 50, 40-44.

Davidson, E. W., Shellabarger, C., Meyer, M. \& Bieber, A. L. (1987b). Binding of the Bacillus sphaericus mosquito larvicidal toxin to cultured insect cells. Canadian Journal of Microbiology 33, 982-989.

Davidson, E. W., Oei, C., Meyer, M., Bieber, A. L., Hindley, J. \& BERRY, C. (1990). Interaction of the Bacillus sphaericus mosquito larvicidal proteins. Canadian Journal of Microbiology 36, 870-878.

GuAN, K. L. \& Dixon, J. E. (1991). Eukaryotic proteins expressed in Escherichia coli: an improved thrombin cleavage and purification procedure of fusion proteins with glutathione $S$-transferase. Analytical Biochemistry 192, 262-267.

HARLOW, E. \& LANE, D. (1988). Antibodies : a Laboratory Manual. Cold Spring Harbor, NY: Cold Spring Harbor Laboratory.

van HEYNINGEN, S. (1982). Similarities in the action of different toxins. In Molecular Action of Toxins and Viruses (Molecular Aspects of Cellular Regulation, vol. 2), pp. 169-190. Edited by P. Cohen \& S. van Heyningen. Amsterdam: Elsevier.

LACY, L. A. \& UNDEEN, A. H. (1986). Microbial control of blackflies and mosquitoes. Annual Review of Entomology 31, 265-296.

LAEMMLI, U. K. (1970). Cleavage of structural proteins during the assembly of the head of bacteriophage T4. Nature, London 227, 680685.

Narasu, M. L. \& Gopinathan, K. P. (1986). Purification of larvicidal protein from Bacillus sphaericus 1593. Biochemical and Biophysical Research Communications 141, 756-761.

Oei, C., Hindley, J. \& BerRy, C. (1990). An analysis of the genes encoding the 51.4- and 41.9-kDa toxins of Bacillus sphaericus 2297 by deletion mutagenesis: the construction of fusion proteins. FEMS Microbiology Letters 72, 265-274.

Schroeder, J. M., Chamberlain, C. \& Davidson, E. W. (1989). Resistance to the Bacillus sphaericus toxin in cultured mosquito cells. In Vitro Cellular and Developmental Biology 25, 887-891.

Sebo, P., Bennardo, T., de la Torre, F. \& Szulmajster, J. (1990). Delineation of the minimal portion of the Bacillus sphaericus $1593 \mathrm{M}$ toxin required for the expression of larvicidal activity. European Journal of Biochemistry 194, 161-165.

Sgarrella, F. \& Szulmajster, J. (1987). Purification and characterization of the larvicidal toxin of Bacillus sphaericus $1593 \mathrm{M}$. Biochemical and Biophysical Research Communications 143, 901-907.

Simpson, L. L., Stiles, B. G., ZePEDA, H. H. \& Wilkins, T. D. (1987). Molecular basis for the pathological actions of Clostridium perfringens iota toxin. Infection and Immunity 55, 118-122.

Singh, Y., LePpla, S. H., Bhatnagar, R. \& Friedlander, A. M. (1989). Internalization and processing of Bacillus anthracis lethal toxin by toxin-sensitive and -resistant cells. Journal of Biological Chemistry 264, 11099-11102.

SMITH, D. B. \& Johnson, K. S. (1988). Single-step purification of polypeptides expressed in Escherichia coli as fusions with glutathione $S$-transferase. Gene 6, 31-40.

Yousten, A. A. (1984). Bacillus sphaericus: microbiological factors related to its potential as a mosquito larvicide. Advances in Biotechnological Processes 3, 315-343. 